\title{
Monitoring of Visitors as a Tool of Protected Areas Management
}

\author{
Stanislava Pachrová \\ College of Polytechnics Jihlava, Czech Republic \\ stanislava.pachrova@vspj.cz \\ Petr Chalupa \\ College of Polytechnics Jihlava, Czech Republic \\ petr.chalupa@vspj.cz \\ Eva Janoušková \\ College of Polytechnics Jihlava, Czech Republic \\ eva.janouskova@vspj.cz
}

\author{
Alice Šedivá Neckářová \\ College of Polytechnics Jihlava, Czech Republic \\ alice.sediva@vspj.cz \\ Leoš Štefka \\ PLA Administration Moravský kras, Czech Republic \\ leos.stefka@nature.cz
}

This article reviews the possibilities of using visitor monitoring in the management of a protected area in the example of the Moravian Karst Protected Landscape Area (PLA). The Moravian Karst is the largest and most significant karst area in the Czech Republic. Its location near a large city and its easy accessibility mean that some of the PLA's parts are faced with the negative impacts of overly intensive tourism on rare natural sites and protected species. While the presence of visitors in a protected area is desirable, it is necessary to regulate their activities in the area. The PLA management needs quality information for its decision making, such as on the current characteristics and behaviour of visitors. To obtain this information, primary marketing research was carried out at selected PLA sites from May to September 2018. A questionnaire survey was used to obtain data from 2,100 visitors and to define the Moravian Karst visitor profile. We found that most visitors were attracted to caves open to the public and the Macocha gorge and that almost a quarter of respondents were planning to return to the PLA within six months of questioning. A major challenge for the sustainable development of tourism in the area will be the fact that visitors to the caves are not interested in visiting other localities in the PLA. The data obtained about visitors will be used by the PLA management to formulate measures to redirect visitors from the most-visited locations to the less-visited ones.

Keywords: sustainable tourism, marketing research, visitor profile, destination management, protected landscape area, Moravian Karst

(cc)BY-SA https://doi.org/10.26493/2335-4194.13.67-79 


\section{Introduction}

According to the UNWTO, sustainable tourism can be simply defined as 'tourism that takes full account of its current and future economic, social and environmental impacts, addressing the needs of visitors, the industry, the environment and host communities' (UNEP \& WTO, 2005, p. 12). When focusing on rural areas, where most protected areas are located, tourism has gained significance in recent years (Sánchez-Hernandéz et al., 2016). Sustainably managing tourism is a fundamental objective for most destinations. Tourism is often used as a tool for local development. Sustainable tourism brings advantages for all tourism stakeholders and society as a whole; for example, it helps to create jobs or to generate income. Staying in protected areas significantly improves the physical and mental state of visitors who relax there and learn interesting facts about the area (e.g., through a guided tour in a cave). This interesting and pleasant experience creates positive attitudes in visitors towards the protected area and contributes to the preservation acceptance of these areas by the general public (Pachrová et al., 2019). Tourists' encounters with nature also lead to their pro-environmental behaviour and activities (Mensah, 2019, p. 54). To strengthen the positive impacts of tourism on a rural destination, it is necessary to conserve resources and appreciate the existing heritage. For this purpose, a proactive awareness is promoted in the environmental area (Gallardo Vázquez et al., 2014). However, tourism also creates certain negative impacts, mainly when the carrying capacity of the destination is repeatedly exceeded (e.g., by excessive numbers of visitors); these aspects include pollution, increased erosion, and reduced population or even the extinction of various species can result (Pásková, 2008; Hübelová et al., 2016).

Managing protected areas has to combine both nature protection and the interests of visitors to ensure the sustainable development of the areas. Achieving sustainable tourism is a continuous process, and it requires the constant monitoring of impacts (UNEP \& w T 0,2005$)$. Monitoring and research in protected areas have the potential to describe these various impacts of tourism, to decipher the causes and contexts, to use the acquired knowledge to stimulate desirable behaviour, and to optimise the activities of not only the protected area management but also all the relevant stakeholders, including visitors to the area (Zelenka et al., 2013, p. 61).

Finally, the local population should be managed so as to achieve sustainable development of protected areas, too. As mentioned by Sevšek and Slavič (2017) (among others), locals represent a long-term development factor of protected areas, and they should actively participate and cooperate with a protected area administration.

This article discusses some possibilities of using visitor monitoring in the management of a protected area in the example of the Moravian Karst Protected Landscape Area (PLA). We focus on the possibility of obtaining important, topical, and relevant data for the PLA's management decision-making from primary marketing research; this data describes the current characteristics of visitors and their behaviour. The authors would like to inspire the managers of other protected areas to use marketing research as an effective tool for visitor management and to intensify the discussion among tourism experts on the increasing and severe problem of overtourism in the most attractive nature areas.

The Moravian Karst is the largest and most significant karst area in the Czech Republic. Its location near a large city and its easy accessibility mean that some parts of the PLA face the negative impacts of too intensive tourism on rare natural sites and protected species. While the presence of visitors in a protected area is desirable, it is necessary to regulate their activities in the area. The PLA management needs quality information for its decision-making, such as on their characteristics and behaviours. To obtain this information, a questionnaire survey among 2,100 visitors was carried out in 2018, and the Moravian Karst visitor profile was defined based on it.

The present paper is structured as follows: the introduction is followed by the theoretical framework and a brief description of the PLA Moravian Karst. Next comes the methodology used, and the stated null hypotheses are described. Selected results of the case study and their discussion are then presented. The conclusions underscore the principal results and 
contributions of the paper. Research limitations and future research lines are also provided.

\section{Visitor Management as an Integral Part of Protected Areas' Management}

According to Eagles (2007) and confirmed by other authors on tourism, such as Balmford et al. (2012), or Prouza (2019), the number of visitors to protected areas is increasing. This is especially true for the most attractive locations. Frequently, the number of visitors exceeds the limits recorded in the previous years. With growing numbers of visitors to protected areas, the burden that tourism puts on treasured sites is sharply increasing; therefore, the importance of managing protected areas is also increasing, and along with it the task to ensure not only the protection of nature and the landscape for future generations, but also to ensure the sustainable use of the area by the general public and thus the adequacy of tourism itself. Visitor management is an integral part of protected area management and, after the creation of a protected area, management specifying human use of the area is developed (Newsome \& Moore, 2017, p. 264). In protected areas, there is not only unique nature but also places with sites of cultural heritage (e.g., caves with archaeological points of interest). Visitor management of protected areas should, therefore, not forget that some visitors have culturally oriented tourist motives (Belij, 2017).

Currently, destination management is considered the most effective way of planning and managing the sustainable development of tourism in any area. The basic principle of destination management is cooperation (Wang, 2008). General cooperation should ensure cooperation between all stakeholders in the tourism of the destination through the destination management organisation, which maintains mutually effective communication and facilitates the coordination of the activities in planning, organising, and decisionmaking that take place in the destination (Holešinská, 2012, p. 47). The management of the protected area should cooperate in various ways with the local destination management organisation in the destination management area, while not excluding that the organisation engaged in protected area management sepa- rately undertakes the activities of destination management in that area. Also important is the cooperation between nearby destinations (Ness et al., 2014), as well as those with protected areas; networking can help to solve many problems because it enables them, for example, to share good cases of management measures. Recently, the attention of professionals has often been focused on modern technologies and many changes they bring to tourism, including new models of destination management (Donald et al., 2019; Ivars-Baidal et al., 2019).

Destination management and, therefore, the management of the tourism of protected areas should always include visitor management in their activities. Sustainable visitor management is, according to Newsome and Moore (2017, p. 261), achieved as a combination of different approaches (e.g., controlling the size, type and spatial extent of visitor activities in combination with various educational programmes) and the application of modern technologies. Basic visitor management attempts to guide the flow of visitors in the time and space of the destination in such a way as to minimise the negative impacts of tourism on the area. Visitor management simultaneously attempts to positively motivate visitors on how to behave with concern for the environment in the given area.

Visitor management of the protected area can use many tools, for example, the marking and maintenance of hiking trails, the building of visitor centres, offering guided tours, introducing/regulating admission to the protected area, introducing limits on visitor numbers to the most vulnerable parts of protected areas, providing clear and up-to-date information available on the website of the protected area, among others.

A significant current challenge is using modern technologies for visitor management in protected areas, such as mobile learning in environmental interpretation and visitor education (Tan \& Law, 2016). A tool that has not been mentioned yet, but is significant for decision-making processes in the management of protected areas, is primary research. Research should be done on various topics, such as natural and landscape conditions and their development, including changes caused by tourism activities in an area. 
Uncontrolled and unmanaged visitors can easily and adversely affect the core values of a protected area. As revealed by Foin et al. (1977), visitors can cause changes in density and species composition of vegetation and animal populations. Protected area management sometimes has to control the resource damage from tourism being restrictive even if it can lead to backlash responses from visitors (Bixler et al., 1992). Typical measures of visitor management in karst areas are restrictive. Tour guide services are provided as the only legitimate way to visit caves (Tomic et al., 2019) and the determination of a maximum visitor capacity per one cave tour (Calaforra et al., 2003).

\section{Visitor Monitoring in Protected Areas}

For visitor management to be done effectively and efficiently, the management of the protected area needs a great deal of information about visitors. For this purpose, visitor monitoring within the protected area is carried out. Summary reviews of the locations where visitor monitoring studies were conducted over the past ten years, were given by Pickering et al. (2018).

The monitoring of visitors in protected areas is a specific and multidisciplinary field of research. Zelenka et al. (2013, p. 232) state that the monitoring of visitors to the natural and treasured landscapes of the area can vary according to the measurements conducted:

- monitoring the flow of visitors,

- monitoring the activities of visitors,

- monitoring the behaviour of visitors and conflicts between them,

- monitoring the characteristics of visitors and their segmentation.

The first mentioned type of visitor monitoring (i.e., monitoring the flow of visitors) is the one most widely used in the protected areas of the Czech Republic, which is usually narrowed down to monitoring the absolute numbers of visitors at selected locations. At present, mainly data from mobile operators or different visitor counters placed in the ground and operated by specialised firms are used for this purpose. In many national parks of America, moreover, the selfregistration of visitors to the area is also common. A purely European approach is, for example, data taken from summit books (Muhar et al., 2002, p. 3). In the case in which entry to some locations in the protected area is not free, the data on the number of tickets sold is used to record the number of visitors (e.g., caves open to the public). Integrated visitor monitoring, monitoring using a combination of several methods for obtaining data (long-term video monitoring, counts by human observers, specific visitor interviews and route analysis by the GIS tools, etc.) seems to be the most effective approach (Arnberger \& Hinterberger, 2004). This is very interesting, because a cost-effective approach to visitor monitoring can be using crowdsourced data (Rice et al., 2019).

Other types of visitor monitoring, especially monitoring the characteristics of visitors and segmenting them, are much more difficult to implement systematically for protected area management. The data can be obtained, for example, from primary marketing research, while the disadvantage in obtaining data is the need for more time, personnel availability, expertise, and financial resources. Another innovative source of information about visitors is an analysis of big data from social media (Pickering et al., 2018). Supporting information is also usually provided by tourist information centres in the area, by the visitor centres of protected areas, or by the wardens and staff of protected areas.

As mentioned by Ballantyne et al. (2011), a visitor's experience can impact their future behaviour. Visitor satisfaction is the best tool for their attachment to the place (Trakolis \& Harding, 1981). The quality of the experience and visitors' satisfaction with the services provided in protected areas should form the basis of visitor management. These two factors should systematically be surveyed as part of visitor monitoring (Eagles, 2007; Tonge \& Moore, 2007; Huang et al., 2008; Samuel et al., 2008; Musa et al., 2017; Oviedo-Garcia et al., 2019).

\section{Moravian Karst Protected Landscape Area}

The Moravian Karst PLA is located in the south-eastern part of the Czech Republic, close to Brno. The PLA was declared there in 1956, covering an area of almost $100 \mathrm{~km}^{2}$; it is the largest and most extensive karst area 
in the Czech Republic, and more than 1,100 caves are located in Devonian limestone. Five cave systems are open to the public and are visited every year by approximately 400,000 people (see http://moravskykras .ochranaprirody.cz).

Karst areas are not typical tourist attractions; most of them have extraordinary scientific and social importance, not only because they represent remarkable geological and geomorphological phenomena, but they also preserve valuable evidence about the origin and evolution of life or the origin and development of human culture. The Moravian Karst area is a good example of this. From the scientific perspective, it is valuable, but for visitors to the area, the surface and subsurface of the karst landscape offer highly attractive features (extensive cave systems, abyss, sinkholes, sinking and gaining streams of water, deep canyon gorges, etc.). In addition, the PLA is interesting in that there are 21 species of bats and many invertebrate species unique in the world (endemic) have been described here. In 2004, the Punkva cave system was included by the Ramsar Convention among internationally significant wetlands. From the cultural and historical points of view, the importance of the Moravian Karst PLA is that it offers various evidence on the development of human society from the Palaeolithic Age to the present (Hübelová et al., 2017; Chalupa \& Veselovský, 2018).

In the surveyed area of the Moravian Karst, the trend of increasing numbers of visitors can be seen: visitors to the caves increased between 2010 to 2018 by more than 22\% (Štefka, personal communication, July 12, 2019). As stated by Pachrová et al. (2019), one of the main problems of tourism in the Moravian Karst is its pronounced seasonality: most visitors come to the PLA in the summer to visit the accessible caves and the Macocha gorge. In these locations, the intensity of tourism is already too strong, and damage is occurring to this unique environment. The PLA management, therefore, needs to take corrective measures within the visitor management of the area.

Mass tourism and insufficient protection of the unique underground of the Moravian Karst has destroyed more than half of the dripstone decoration in some parts of the caves (Štefka, 2013). Now, all drip- stone decoration is strictly protected, and visitors are not allowed to touch it. The needs of visitors and needs of nature protection had to be harmonised regarding the use of lights in the caves. The extremely negative impact of excessively intensive lighting in the caves was described by Štefka (2016): the lights used for enabling visitors to see in the caves caused the appearance of green plants in large parts of the visited underground. This factor, absolutely foreign for the cave environment, had to be cleaned away. Unfortunately, cleaning caves was done by furbishing or by using chemicals that harmed the sensitive environment. As a result, rules for lighting in the caves, including the timing of light periods and the intensity of light, are carefully managed now.

The importance of setting strict limits for numbers of visitors per day to the caves was proved Lang et al. (2017), who discovered that when visitors were present the anthropogenic $\mathrm{CO}_{2}$ flux in Výpustek Cave exceeded all other $\mathrm{CO}_{2}$ fluxes and that intervals between visitor groups would have to be up to six hours long if the cave environment were to return to natural conditions. Karst places decorated with ice during winter (small caves near the surface) are also very attractive for visitors. As stated by Ždímal (2015), some visitors to the Moravian Karst crawl through small tunnels and destroy valuable local plant and animal communities. Moreover, new tourism activities potentially dangerous for the environment are being developed in the Moravian Karst now, such as single trails for mountain bikers (Fialová et al., 2019). The need for visitor management in the researched area is obvious. Nevertheless, according to Leslie (2015, p. 56), people, in general, express their support for all environmental initiatives, including conservation measures. Lorencová et al. (2014) conducted a questionnaire survey among visitors of Moravian Karst and stated that most tourists do not feel limited by conservation measures, which is a very positive finding for the PLA's Administration and sustainable development of tourism in the area.

\section{Methodology}

This paper aims to review the possibilities of using visitor monitoring in the management of a protected 
area in the case study of the Moravian Karst Protected Landscape Area in the Czech Republic. The authors would like to inspire other protected area managements to use marketing research more often, because it gives unique and valuable data on visitor management. The results of the research will be used by the PLA Administration to create measures that will lead to a greater spread of visitors throughout the PLA to relieve congestion at the most attractive locations and will also lead to shifting more visitation to the spring and autumn months. The profile of the visitor to the Moravian Karst will serve as background material for creating the management strategy for the protected area in question. The PLA Administration asked for information about the characteristics of visitors and information about their values, attitudes, and behaviour. For effective visitor management, they need to know, for example, if there is a difference in the main reason for visiting the PLA between visitors who come for the first time and those who are returning to the area. For mostly marketing communication of the PLA, it is crucial to know where the visitors come from and if people from closer areas return to the Moravian Karst more often. Based on the mentioned needs of the PLA Administration, we stated and tested two null hypotheses (Hо):

HO1 There is no significant difference in the main reason for visiting the Moravian Karst PLA between first-time visitors and those who are returning to the area repeatedly.

HO2 For visitors to the Moravian Karst, there is no dependence between repeat visits to the protected area and the distance of the home of the respondent.

This article presents selected results of extensive primary research among visitors to the Moravian Karst. The research was carried out by the Department of Travel \& Tourism at the College of Polytechnics Jihlava (VŠPJ) in cooperation with the PLA management of the Moravian Karst. The research was carried out using a quantitative survey method of standardised questionnaires from May to September 2018. The questionnaire had a total of 19 questions (closed, semiclosed, scaled) and was distributed in four languages
(Czech, English, German, and Polish). Data were obtained using the face-to-face survey with visitors at ten designated PLA locations throughout the protected area. The data collected by trained interviewers were anonymous, with the choice of respondents consistently random. In order to prevent any distortion of the surveyed results, for example due to bad weather, the data was collected on different days of the week at different times of the day. A total of 2,100 questionnaires, properly completed, were obtained.

To verify the stated null hypotheses, attention will be given to the geographic, psychographic, and behavioural characteristics of the respondents. The initial data obtained were processed, analysed, and interpreted with mathematical and statistical methods. Concerning the methods, analysis and synthesis were used. Microsoft Excel and Statistica 13 software were used to process the data.

The existence of a conclusive dependence between the selected characteristics of the respondents was proved using the Pearson's chi-square test of independence $\left(\chi^{2}\right)$, provided that a maximum of $20 \%$ of the expected frequencies was less than 5 . For the Pearson statistic $\chi^{2}$, the number of degrees of freedom $(\mathrm{DF})$ is also given for completeness. On the basis of the probability of the distribution of chi-square, the $p$ value was observed for the null hypothesis (assuming the independence of the two selected signs), which is the lowest level of significance for which the null hypothesis can be rejected $(p<0.05)$. The observed $\chi^{2}$ was then interpreted using the method of correspondence analysis. Correspondence analysis is a multivariate statistical method that allows the display and summary of a set of data in a two-dimensional graphic form. It is traditionally applied to contingency tables; correspondence analysis decomposes the chi-squared statistic associated with this table into orthogonal factors. The distance between single points is defined as a chi-squared distance. This analysis aims to reduce the multidimensional space of row and column profiles and to save as much of the original data as possible (Hebák et al., 2007). The total variance of the data matrix is measured by the inertia (Greenacre, 1984), which resembles a chi-square statistic but is calculated based on relative observed and expected frequencies. 
Table 1 Sociodemographic Structure of Respondents

\begin{tabular}{llrr}
\hline Respondents characteristics & $N$ & $\%$ \\
\hline Gender & Women & 1,028 & 49 \\
& Men & 1,072 & 51 \\
& Total & 2,100 & 100 \\
\hline Age & Up to 24 years & 294 & 14 \\
& 25-34 years & 512 & 24 \\
& 35-49 years & 843 & 40 \\
& 50-59 years & 285 & 14 \\
& 60+ & 166 & 8 \\
& Total & 2,100 & 100 \\
\hline Education & Without high school & 452 & 22 \\
& High school & 1,217 & 58 \\
& University & 431 & 20 \\
& Total & 2,100 & 100 \\
\hline
\end{tabular}

All tables and figures in this article are the joint work of the authors.

\section{Results and Discussion}

During the primary research carried out, 2,100 questionnaires properly completed by visitors to the Moravian Karst were obtained $(N=2,100)$. The sociodemographic characteristics of the respondents are shown in Table 1, which indicates that, in a representative sample of visitors to the PLA, the share of men is $51 \%$ and women $49 \%$. It can be concluded from this result that men and women visit the Moravian Karst in equal proportion.

All age categories were represented in the research. People aged 35-49 were the predominant group in the structure of visitors, accounting for $40 \%$ of the total number of respondents (Table 1). Nearly a quarter of visitors $(24 \%)$ are in the age segment of $25-34$ years old. The age categories of 24 years old and less, and 50-59 had an equal share of $14 \%$ of the total number of respondents. The least numerically represented age category of visitors were seniors (i.e., 60 and older). The age structure of visitors is very similar to the one observed by Lorencová et al. (2014) in 2013, so we can conclude that in a long-term view a majority of the PLA's visitors is between 25 to 49 years of age.
The structure of visitors to the PLA according to the highest level of education reached shows that almost $80 \%$ of visitors had at least a high school degree, and one fifth of the total number of respondents had a university education (Table 1). The remaining fifth, (i.e., 452 respondents) had a basic education or apprenticeship. This number, however, included $195 \mathrm{sec}-$ ondary school students ( $9 \%$ of the total respondents), who can be expected to continue with their education. The results of our research show that visitors to the surveyed PLA are mostly well educated, which confirms the trend of tourism in protected areas as published by Eagles (2007) and confirmed by Zelenka et al. (2013, p. 70), as well as Newsome and Moore (2017, p. 261). These authors suggest that protected areas are exploited mainly by educated people expecting an experience full of interesting information and things to do, but who also expect sophisticated services and management of the area. Visitor management of the Moravian Karst should take this into account, because the right choice of marketing tools and provision of quality services could quite easily motivate this group of visitors to make repeat visits, even outside the main summer season; it is also possible, given these visitors' interest in new information and experiences, to redirect them to less exposed tourist parts of the PLA.

Due to the age structure of the respondents (Table 1), it is not surprising that the Internet is the main medium from which visitors to the PLA get information for their visit (31\% of respondents). The second most important source of data ( $27 \%$ of respondents) is information from friends and relatives, transmitted not only by word-of-mouth but also through various social media, which underscores the need of visitor management of the protected area to have a clear, updated, and interesting presentation of visitor services on the internet, as well as the need to provide quality services to receive positive reviews and recommendations. For visitor management of the researched area, it is crucial to recognise that the combination of these two sources of information makes it possible to reach the majority of visitors, and some of them can certainly be motivated to visit (e.g., a selected cave in winter), when they will have the unique experience of the karst in wintertime with a minimum number of other vis- 
itors, and the cave will probably be pleasantly warm (compared to outdoor temperatures).

In the context of the geographic structure of respondents, whether they came from the Czech Republic or abroad was determined. The questionnaire showed that the Moravian Karst is a destination mainly for domestic tourism. Of the total respondents, only $4 \%$ were foreign visitors. In the structure of foreign visitors, most respondents were from Slovakia; the second most frequently cited country of origin was Poland; the third was Russia. The largest representation of Slovaks among visitors from abroad also prove Lorencová et al. (2014). It can have various reasons, for example, not too great a distance of the Moravian Karst from Slovakia, or that many Slovaks live in the Czech Republic. In the ratio of Czech and foreign visitors, the results of our research contradict the information of the Moravian Karst Cave Administration, which indicates that visitors from abroad account for approximately one-third of the total number of visitors to the area (Enviweb.cz, 2017). It needs to be taken into account, however, that the information from the cave administration is based on the tickets sold to publicly-accessible caves, while our data were obtained at various locations throughout the protected area. Both sources of information nevertheless agree on the most common countries of origin of foreign visitors as well as on the fact that the number of visitors to the PLA, for whom the main reason for their visit to the protected area is a tour of the caves, accounted for less than half of the total number of visitors to the area (Table 2). This agreement confirms, among other things, the relevance of the results of our research. The authors of the paper are, therefore, inclined to see the results of their research as corresponding better to the real situation in relation to the entire PLA, and so the share of foreign visitors to the Moravian Karst is significantly lower than the overall number of visitors given by Enviweb.cz (2017).

For visitor management and maintaining the sustainable tourism of the PLA, the research implies the positive fact that almost $70 \%$ of visitors return to this protected area, 30\% even repeatedly (i.e., they had been there at least five times at the time of data collection) (Table 2). Of the total number of respondents
Table 2 Reason for Visiting the Moravian Karst PL A in Dependence on the Frequency of the Destination Visit

\begin{tabular}{|c|c|c|c|c|c|}
\hline Reason for visit & (1) & (2) & (3) & (4) & (5) \\
\hline \multirow{2}{*}{$\begin{array}{l}\text { Exploring natural } \\
\text { attractions (caves) }\end{array}$} & A & 360 & 391 & 177 & \multirow[t]{2}{*}{928} \\
\hline & $\mathrm{S}$ & 55.4 & 47.9 & 27.9 & \\
\hline \multirow[t]{2}{*}{ Sightseeing } & A & 48 & 50 & 26 & \multirow[t]{2}{*}{124} \\
\hline & s & 7.4 & 6.1 & 4.1 & \\
\hline \multirow[t]{2}{*}{ Relaxation } & A & 80 & 155 & 170 & \multirow[t]{2}{*}{405} \\
\hline & s & 12.3 & 19.0 & 26.8 & \\
\hline \multirow[t]{2}{*}{ Hiking, cycling, etc. } & A & 89 & 114 & 162 & \multirow[t]{2}{*}{365} \\
\hline & s & 13.7 & 14.0 & 25.5 & \\
\hline \multirow{2}{*}{$\begin{array}{l}\text { House of Nature of the } \\
\text { Moravian Karst }\end{array}$} & A & 13 & 28 & 8 & \multirow[t]{2}{*}{49} \\
\hline & s & 2.0 & 3.4 & 1.3 & \\
\hline \multirow[t]{2}{*}{ Sport } & A & 8 & 8 & 9 & \multirow[t]{2}{*}{25} \\
\hline & s & 1.2 & 1.0 & 1.4 & \\
\hline \multirow[t]{2}{*}{ Work } & A & 13 & 14 & 15 & \multirow[t]{2}{*}{42} \\
\hline & s & 2.0 & 1.8 & 2.4 & \\
\hline \multirow[t]{2}{*}{ Entertainment } & A & 4 & 28 & 23 & \multirow[t]{2}{*}{55} \\
\hline & s & 0.6 & 3.4 & 3.6 & \\
\hline \multirow[t]{2}{*}{ Visit to relatives/friends } & A & 28 & 22 & 34 & \multirow[t]{2}{*}{84} \\
\hline & s & $4 \cdot 3$ & 2.7 & 5.4 & \\
\hline \multirow[t]{2}{*}{ Transit } & A & 7 & 6 & 10 & \multirow[t]{2}{*}{23} \\
\hline & $\mathrm{s}$ & 1.1 & 0.7 & 1.6 & \\
\hline \multirow[t]{3}{*}{ Total } & A & 650 & 816 & 634 & 2,100 \\
\hline & $\mathrm{R}$ & 31 & 39 & 30 & 100 \\
\hline & s & 100 & 100 & 100 & - \\
\hline
\end{tabular}

Notes Column headings are as follows: (1) frequency: A absolute, s - column relative (\%), $\mathrm{R}$ - relative (\%), (2) 1st visit, (3) 2nd-4th visits, (4) 5th and further visits, (5) total. $\chi^{2}=167.2909, \mathrm{DF}=18, p=0.0000$.

$(N=2,100), 650$ were visiting the area for the first time, (i.e., $31 \%$ ).

The statistical processing of the null hypothesis Ho1 with Person's chi-square test showed a significant dependence between the main reason for visiting the Moravian Karst and the frequency of visiting this protected area. When testing the independence of the two variables, the values of the test statistic $\chi^{2}=167.2909$ and $p=0.0000$ were calculated; the Ho1 null hypoth- 


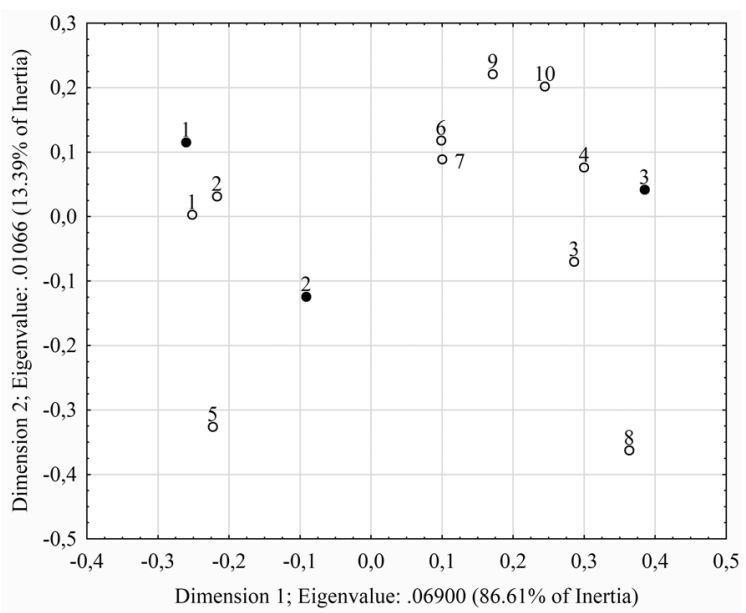

Figure 1 The Correspondence Analysis: The Dependence of the Reason for Visiting the Moravian Karst PL A to the Frequency of the Destination Visit (2D plot of row and column coordinates, dimension: $1 \times 2$; input table (rows $\times$ columns): $3 \times 10$; standardization: row and column profiles; dark - visit frequency, light - reason for visit)

esis was rejected at the level of significance of $5 \%$ (Table 2). The corresponding analysis of examining both variables suggests that there is a significant difference between the main reason for visiting the destination among first-time visitors and among visitors repeatedly coming back (i.e., those who have been to the area at least five times) (Figure 1).

The first visit to the PLA is most often logically focused on becoming acquainted with the most famous attractions in the area (i.e., the caves), while for repeat visitors the predominant reason is the desire for active leisure in the beautiful natural environment, whether for relaxing walks, hiking, or biking. While the majority of first-time visitors (55.4\%) said their main reason for visiting the PLA was to 'explore natural attractions - caves', it was the reason for only $27.9 \%$ of repeat visitors.

In contrast, only $26 \%$ of first-time visitors indicated active leisure in the PLA natural environment, but it was the reason for $52.3 \%$ of repeat visitors to the area (Table 2). Moreover, one quarter of respondents were planning to return to the PLA within six months of questioning, and $52 \%$ of respondents want to come

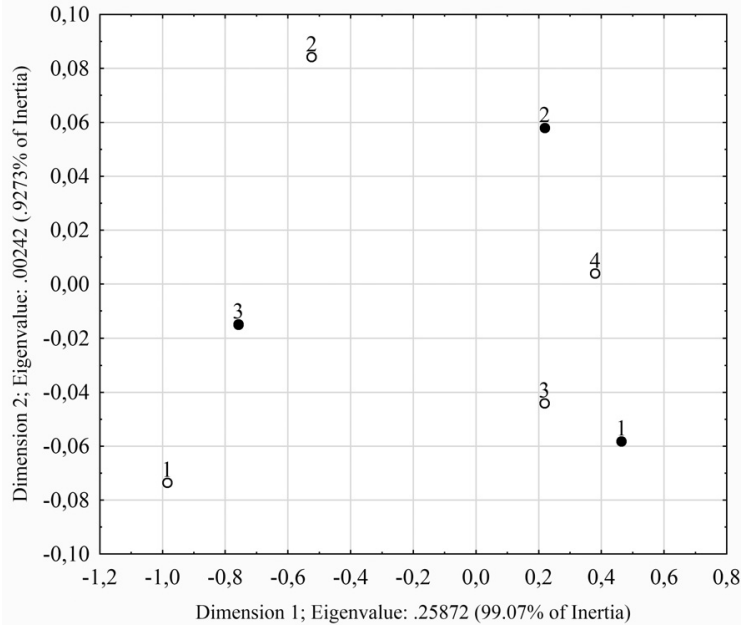

Figure 2 The Correspondence Analysis: The Dependence of the Distance from Visitor's Residence to the Frequency of the Moravian Karst PL A Visits (2D plot of row and column coordinates, dimension: $1 \times 2$; input table (rows $\times$ columns): $3 \times 4$; standardization: row and column profiles; dark visit frequency, light - residence distance)

back too, but not so soon. A major challenge for the sustainable development of tourism in the area will be the fact that visitors to the caves are not interested in visiting other localities in the PLA during their visit. For visitor management of the PLA, these research results are significant in that they demonstrate that repeat visitors are greatly interested in other locations of the protected area than the accessible tourist caves and the Macocha gorge, and they need much more attention in the visitor management in future.

We can also see that Moravian Karst has some specific characteristics in terms of the main reasons for visiting this area. Visitors come here mainly to explore the natural attractions, then to relax and to do sports. Entertainment was the main reason for less than 3\% of respondents. In contradistinction, Navrátil et al. (2015) revealed that most important for tourists in the protected areas in the southern part of the Czech Republic are relaxation, entertainment, and recreational sports activities.

Furthermore, the stated $\mathrm{HO} 2$ null hypothesis was tested, for which the assumption was made that among visitors to the Moravian Karst PLA, repeat visits to the 
Table 3 Distance from Visitor's Residence in Dependence on the Frequency of the Moravian Karst PLA Visits

\begin{tabular}{lcrrrr}
\hline Residence distance & $(1)$ & $(2)$ & $(3)$ & $(4)$ & $(5)$ \\
\hline Up to $20 \mathrm{~km}$ & $\mathrm{~A}$ & 16 & 52 & 206 & 274 \\
& $\mathrm{~s}$ & 2 & 6 & 33 & \\
\hline $21-50 \mathrm{~km}$ & $\mathrm{~A}$ & 52 & 135 & 211 & 398 \\
& $\mathrm{~s}$ & 8 & 17 & 33 & \\
\hline $51-100 \mathrm{~km}$ & $\mathrm{~A}$ & 153 & 160 & 82 & 395 \\
& $\mathrm{~S}$ & 24 & 20 & 13 & \\
\hline Above $100 \mathrm{~km}$ & $\mathrm{~A}$ & 429 & 469 & 135 & 1,033 \\
& $\mathrm{~S}$ & 66 & 57 & 21 & \\
\hline Total & $\mathrm{A}$ & 650 & 816 & 634 & 2,100 \\
& $\mathrm{R}$ & 31 & 39 & 30 & 100 \\
& $\mathrm{~S}$ & 100 & 100 & 100 & - \\
\hline
\end{tabular}

Notes Column headings are as follows: (1) frequency: A absolute, $\mathrm{s}$ - column relative (\%), $\mathrm{R}$ - relative (\%), (2) 1st visit, (3) 2nd -4 th visits, (4) 5th and further visits, (5) total. $\chi^{2}=548.398, \mathrm{DF}=6, p=0.0000$.

area are not dependent on the distance of the respondent's home. Pearson's chi-square test showed a significant statistical dependence of both variables, because $\chi^{2}=548.398$ and $p=0.0000$ (Table 3); we, therefore, reject the Hо2 null hypothesis at the significance level of $5 \%$. Figure 2, a biplot created using the correspondence analysis method, shows that respondents residing within $20 \mathrm{~km}$ of the surveyed site are clearly the most frequent visitors to the Moravian Karst. Twothirds of repeat visitors to the area reside within $50 \mathrm{~km}$ of the PLA. Interestingly, more than a fifth of repeat visitors to the surveyed area come from a distance of over $100 \mathrm{~km}$. Almost $70 \%$ of first-time visitors come from a distance of over $100 \mathrm{~km}$ from the PL A (Table 3). For visitor management of the protected area, it is recognised that people not only from the surrounding area are repeatedly returning to the PLA, again important information. This fact confirms the high attractiveness of the area for tourism, and management could use it in their marketing activities, especially in an effort to disperse visitors across the PLA, ideally in combination with the previous finding regarding the main reasons for repeat visits by the respondents.

\section{Conclusion}

Protected areas around the world are seeing a growing public interest in visiting them, and in many places valuable natural and landscape features are under threat from overly heavy a tourist burden. This is the current problem of the Moravian Karst PLA, the largest and most popular karst area in the Czech Republic.

This article shows the possibilities of using visitor monitoring in the visitor management of the protected area in the example of the Moravian Karst Protected Landscape Area and serves as a case study that could inspire other protected area managements to use primary marketing research more often as an effective tool for obtaining data needed for sustainable tourism management of the given area. The data obtained directly from visitors enables not only the creation of their exact profiles and segmentation of them, but also provides valuable data on the motivation to visit the area, data on the planned and real behaviour of visitors, their satisfaction with their stay in the destination, and similar.

The results of the research into the Moravian Karst Protected Landscape Area showed that this protected area is visited by men and women in balanced proportion and that the structure of visitors is significantly predominated by persons aged 35-49. Furthermore, almost $80 \%$ of visitors to the surveyed PLA have at least completed secondary education. This fact should be exploited by the visitor management of the Moravian Karst PLA, as this group of visitors can be easily motivated for repeated visits and can be redirected to less exposed parts of the PLA. The results of the research also show that the surveyed area is primarily a destination for domestic tourism and that the main motive for visiting the destination is, for almost half of the total number of visitors, to become acquainted with tourist-accessible caves. The vast majority of visitors (almost 70\%) return to the Moravian Karst PLA and $30 \%$ of the total number even repeatedly.

The stated Ho1 null hypothesis, which assumed there is no significant difference in the main reason for visiting the Moravian Karst PLA between first-time visitors and those who repeatedly return to the area, was not confirmed. The statistical processing of the 
data by Pearson's chi-square test showed a significant dependence between both variables analysed. It has been proven that the first visit to the PLA is most often focused on becoming acquainted with the most famous attractions of the area (the caves) while repeat visitors are mostly motivated by the desire for active leisure (relaxing on walks, hiking or biking). This result for visitor management of the PLA is significant in that repeat visitors have shown great interest in other areas of the protected area than the tourist-accessible caves and the Macocha gorge.

The stated но2 null hypothesis, which assumed that repeat visits to the Moravian Karst PL A do not depend on the distance of the respondent's residence, was also not confirmed. Pearson's chi-square test showed a significant statistical dependence of both variables. Respondents residing within $20 \mathrm{~km}$ of the place of inquiry are clearly the most frequent visitors returning to the PLA. With the combination of the knowledge that returning visitors to the PLA are more interested in getting to know new sites of the protected area, visitor management of the Moravian Karst PLA should also work on trying to relieve the most burdened sites.

Our article has provided much new information about the profile of visitors to the Moravian Karst PLA, which is practical in the management of visitors to this area. The primary limitation of the research conducted is that the data collected in the field was not year-round and did not cover at least one whole tourist season. However, due to the chosen methodology of data collection and well-trained interviewers, our research results are sufficiently representative. The continuous collection and subsequent evaluation of data on visiting a destination are essential for the sustainable management of tourism in any area. Our research should, therefore, be followed up by further research, which would be conducted throughout the year and provide, for example, information on the prevailing motivation to visit the PLA outside the main tourism season and during the winter.

\section{Acknowledgments}

The paper was created with the financial support of project No. 1170/026/o13 of the College of Polytechnics Jihlava.

\section{References}

Arnberger, A., \& Hinterberger, B. (2004). Visitor monitoring methods for managing public use pressures in the Danube Floodplains National Park, Austria. Journal for Nature Conservation, 11(4), 260-267.

Ballantyne, R., Packer, J., \& Sutherland, L. A. (2011). Visitor's memories of wildlife tourism: Implications for the design of powerful interpretive experiences. Tourism Management 32(4), 770-779.

Balmford, A., Beresford, J., Green, J., Naidoo, R., Walpole, M., \& Manica, A. (2012). Trends in nature-based tourism. In J. A. Seba (Ed.), Ecotourism and sustainable tourism: New perspectives and studies (pp. 30-37). Apple Academic Press.

Belij, M. (2017). Cultural tourist motives in national parks in Serbia. In D. Filipović, A. Gosar, M. Koderman, \& S. Đurđić (Eds.), Tourism in protected areas of nature in Serbia and Slovenia (pp. 113-128). University of Belgrade.

Bixler, R. D., Noe, F. P., \& Hammitt, W. E. (1992). Restrictive and non-restrictive management of park visitors. Journal of Environmental Systems, 21(4), 335-348.

Calaforra, J. M., Fernandez-Cortes, A., Sanchez-Martos, F., Gisbert, J., \& Pulido-Bosch, A. (2003). Environmental control for determining human impact and permanent visitor capacity in a potential show cave before tourist use. Environmental Conservation, 30(2), 160-167.

Chalupa, P., \& Veselovský, J. (2018). Link of the natural and human components of the geosphere in historical development as a motivation for the visit of Moravian karst. Geografické informácie, 22(P T1), 163-179.

Donald, R., Seo, Y., \& Kemper, J. (2019). Complaining practices on social media in tourism: A value co-creation and co-destruction perspective. Tourism Management, 73, 35-45.

Eagles, P. (2007). Global trends affecting tourism in protected areas. In R. Bushell, \& P. Eagles (Eds.), Tourism and protected areas: Benefits beyond boundaries (pp. 2743). САВ I.

Enviweb.cz. (2017, 21 January). Návštěvnost jeskyní Moravského krasu byla loni nejvyšši od 2007. http://www.enviweb .cz/107610

Fialová, J., Březina, D., Žižlavská, N., Michal, J., \& Machar, I. (2019). Assessment of visitor preferences and attendance to singletrails in the Moravian karst for the sustainable development proposals. Sustainability, 11(13). https://doi.org/10.339o/su11133560

Foin, T. C., Garton, E. O., Bowen, C. W., Everingham, J. M., \& Schultz, R. O. (1977). Quantitative studies of visitor impacts on environments of Yosemite National-park, Cali- 
fornia, and their implications for park management policy. Journal of Environmental Management, 5(1), 1-22.

Gallardo Vázquez, D., Sánchez Hernández, M. I., \& Ferraz, F. (2014). Grado de divulgación de la información social en los establecimientos de turismo rural en la Península Ibérica. Revista de la Asociación Espaňola de Contabilidad y Administración de Empresa, 108, 15-18.

Greenacre, M. J. (1984). Theory and applications of correspondence analysis. Academic Press.

Hebák, P., Hustopecký, J., Pecáková, I., Průša, M., Řezanková, H., Svobodová, A., \& Vlach, P. (2007). Vícerozměrné statistické metody 3. Informatorium.

Holešinská, A. (2012). Destinační management jako nástroj regionální politiky cestovního ruchu. Masaryk University.

Huang, Y., Deng, J. Y., Li, J., \& Zhong, Y. D. (2008). Visitors' attitudes towards China's national forest park policy, roles and functions, and appropriate use. Journal of Sustainable Tourism, 16(1), 63-84.

Hübelová, D., Chalupa, P., \& Pavlík, I. (2016). Selected risks of deterioration by human activity in Protected Landscape Area of Moravian Karst. In S. Pachrová \& M. Doležalová (Eds.), Proceedings of 11th International Conference on Topical Issues of Tourism: Local Heritage and Tourism (pp. 126-138). College of Polytechnics Jihlava.

Hübelová, D., Konečný, O., Geršl, M., \& Pavlík, I. (2017). Attendance in to Moravian Karst in relation to sustainable region development and tourist industry during the years 2012-2015. In S. Pachrová, I. Linderová, \& M. Doležalová (Eds.), Proceedings of the 12th International Conference on Topical Issues of Tourism (pp. 104-114). College of Polytechnics Jihlava.

Ivars-Baidal, J. A., Celdran-Bernabeu, M. A., Mazon, J. N., \& Perles-Ivars, A. F. (2019). Smart destinations and the evolution of ICT S: A new scenario for destination management? Current Issues in Tourism, 22(13), 1581-16oo.

Lang, M., Faimon, J., Pracný, P., \& Kejíková, S. (2017). A show cave management: Anthropogenic $\mathrm{CO}_{2}$ in atmosphere of Vypustek Cave (Moravian Karst, Czech Republic). Journal for Nature Conservation, 35, 40-52.

Leslie, D. (2015). The consumers of tourism. In D. Leslie (Ed.), Responsible tourism: Concepts, theory and practice (pp. 54-71). САВI.

Lorencová, H., Slezáčková, T., \& Schneider, J. (2014). Profile of visitors to the Moravian Karst PLA as a basis for solving visitors impacts on nature protection. In Proceedings from IX. International Conference on Applied Business Research ICABR 2014 (pp. 621-630). Mendel University in Brno.

Mensah, I. (2019). Environmental management concepts and practices for the hospitality industry. Cambridge Scholars Publishing.

Muhar, A., Arnberger, A., \& Brandenburg, Ch. (2002). Methods for visitor monitoring in recreational and protected areas: An overview. In A. Arnberger, C. Brandenburg, \& A. Muhar (Eds.), Monitoring and management of visitor flows in recreational and protected areas (pp. 1-6). Bodenkultur University.

Musa, G., Najmin, S., Thirumoorthi, T., \& Taha, A. Z. (2017). Examining visitors' experience with Batu Cave, using the four realm experiential theory. International Journal of Tourism Cities, 3(2), 105-120.

Navrátil, J., Knotek, J., Pícha, K., \& Fialová, J. (2015). The protected areas: Are they still in the 'pleasure periphery' or are they destinations for sustainable tourism activities? European Journal of Tourism Research, 11, 57-72.

Ness, H., Aarstad, J., Haugland, S. A., \& Gronseth, B. O. (2014). Destination development: The role of interdestination bridge ties. Journal of Travel Research, 53(2), 183195 .

Newsome, D., \& Moore, S. (2017). Managing visitors to the natural environment. In C. M. Hall, S. Gössling, \& D. Scott (Eds.), The Routledge handbook of tourism and sustainability (pp. 261-269). Routledge.

Oviedo-Garcia, M. A., Vega-Vazquez, M., Castellanos-Verdugo, M., \& Orgaz-Aguera, F. (2019). Tourism in protected areas and the impact of servicescape on tourist satisfaction, key in sustainability. Journal of Destination Marketing \& Management, 12, 74-83.

Pachrová, S., Janoušková, E., \& Chalupa, P. (2019). Services quality evaluation as a tool for visitor management of protected areas: A case study of Moravian karst. In J. Fialová (Ed.), Public recreation and landscape protection (pp. 344-347). Mendel University in Brno.

Pásková, M. (2008). Udržitelnost rozvoje cestovního ruchu. Gaudeamus.

Pickering, C., Dario Rossi, S., Hernando, A., \& Barros, A. (2018). Current knowledge and future research directions for the monitoring and management of visitors in recreational and protected areas. Journal of Outdoor Recreation and Tourism, 21, 10-18.

Prouza, V. (2019, April 26). Krkonoše opět v obležení návštěvníkủ. Novinky.cz. https://www.novinky.cz/cestovani/ clanek/krkonose-opet-v-oblezeni-navstevniku $-40281222$

Rice, W. L., Mueller, J. T., Graefe, A. R., \& Taff, B. D. (2019). Detailing an approach for cost-effective visitor-use monitoring using crowdsourced activity data. Journal of Park and Recreation Administration, 37(2), 144-154. 
Samuel, S. K., Miju, K., \& Jungwoong, P. (2008). Cave tourism: Tourists' characteristics, motivations to visit, and the segmentation of their behavior. Asia Pacific Journal of Tourism Research, 13(3), 299-318.

Sánchez-Hernández, M. I., Gallardo-Vázquez, D., \& GalánLadero, M. M. (2016). How social responsibility certification can help rural tourism. In E. Kastenholz, M. J. Carneiro, C. Eusébio, \& E. Figueiredo (Eds.), Meeting challenges for rural tourism through co-creation of sustainable tourist experiences (pp. 391-414). Cambridge Scholars.

Sevšek, M., \& Slavič, I. P. (2017). (Un)involvement of the local population in the development of the protected area: The case of landscape park Kum, Slovenia. In D. Filipović, A. Gosar, M. Koderman, \& S. Đurđić (Eds.), Tourism in protected areas of nature in Serbia and Slovenia (pp. 141-159). University of Belgrade.

Štefka, L. (2013). Show caves and the environment. In Proceedings of the conference Public recreation and landscape protection (pp. 154-158). Mendel University in Brno.

Štefka, L. (2016). Tourism and touristic industry in Moravian Karst from the view of nature protection. In Proceedings of international scientific conference on Region in the development of the society (pp. 975-982). Mendel University in Brno.

Tan, E., \& Law, R. (2016). mLearning as a softer visitor management approach for sustainable tourism. Journal of Sustainable Tourism, 24(1), 132-152.
Tomic, N., Antic, A., Markovic, S. B., Dordevic, T., Zorn, M., \& Valjavec, M. B. (2019). Exploring the potential for speleotourism development in Eastern Serbia. Geoheritage, 11(2), 359-369.

Tonge, J., \& Moore, S. A. (2007). Importance-satisfaction analysis for marine-park hinterlands: A Western Australian case study. Tourism Management, 28(3), 768-776.

Trakolis, D., \& Harding, D. M. (1981). Visitor satisfaction and attitudes to management of forest recreation areas in North Wales. Quarterly Journal of Forestry, 75(3), 137147.

UNEP \& WTO. (2005). Making tourism more sustainable: A guide for policy makers. United Nations Environment Programme \& World Tourism Organization.

Wang, Y. (2008). Collaborative destination marketing: Roles and strategies of convention and visitors bureaus. Journal of Vacation Marketing, 14(3), 191-209.

Zelenka, J., Těšitel, J., Pásková, M., \& Kušová, D. (2013). Udržitelný cestovní ruch: Management cestovního ruchu $v$ chráněných územích. Gaudeamus.

Ždímal, V. (2015). Places with ice in protected areas and visitors. In J. Fialová \& D. Pernicová (Eds.), Public recreation and landscape protection (pp. 178-180). Mendel University in Brno. 